\title{
Tomasz Cieślak
}

Uniwersytet Łódzki

\section{Geografia i topografia Ziemi Nod Radosława Kobierskiego}

Wydana w 2010 roku powieść Radosława Kobierskiego Ziemia Nod jest trzecim utworem prozatorskim $\mathrm{w}$ jego dorobku ${ }^{1}$. To ogromny, rozpisany na sześćset stron fresk, w chronologicznym porządku, niebudującym jednak spójnego wielkiego łańcucha przyczynowo-skutkowego, lecz szkicowo, migawkowo ujmujący losy kilkudziesięciu bohaterów pochodzących z różnych środowisk i narodowości (głównie Polaków i Żydów) - od międzywojnia po pierwsze lata PRL. Łączy ich wszystkich geografia i topografia: akcja powieści dzieje się w Tarnowie, wśród jego ulic, placów i zaułków oraz w pobliskich wsiach i miasteczkach. Co ważne, Ziemia Nod nie wpisuje się w modny, zwłaszcza w latach 90., nurt literatury małych ojczyzn², która ufundowana została na nostalgicznej wrażliwości ${ }^{3}$. Kobierski nie wprowa-

\footnotetext{
1 R. Kobierski (ur. 1971) debiutował jako poeta w 1997 roku tomem Niedogony, opublikował następnie cztery zbiory wierszy oraz tom opowiadań Wiek rębny (2000) i powieść Harar (2005). Ziemia Nod, Warszawa 2010, nagrodzona została Gwarancją Kultury TVP Kultura, nominowana też była do Literackiej Nagrody Europy Środkowej Angelus 2011 oraz Nagrody Literackiej Gdynia 2011.

2 O renesansie lokalności, ponowoczesnym regionalizmie, zob. m.in.: K. Brakoniecki, Prowincja człowieka. Obraz Warmii i Mazur w literaturze olsztyńskiej, Olsztyn 2003.

3 Przemysław Czapliński trafnie konstatował: „Nostalgia nie rozwiązuje [...] problemów z czasem, lecz je unieważnia; podsuwa nam gotowe miary wartości, pozwalające krytycznie oceniać dzień dzisiejszy, a kasandrycznie wyrokować o przyszłości. Co równie ważne, nostalgia, choć rzekomo rozmiłowana w przeszłości, łatwo może doprowadzić do jej wyjałowienia:
} 
dza Tarnowa w krąg innych zmityzowanych przestrzeni, jak choćby Gdańsk, Wrocław czy Zamość.

Towarzyszący autorowi konsekwentnie swoim recenzenckim piórem Dariusz Nowacki napisał, że "to rzecz dużej urody”, ale dodał też w następnym zdaniu: „nie potrafię powiedzieć, po co - poza tym, żebyśmy ją podziwiali - powstała" - i dalej, skrótowo prezentując zamysł i kompozycję całości, stwierdził:

Historia jest tu przepisana niemal słowo w słowo. Kobierski nie zmaga się z nią, nie układa jej i nie interpretuje po swojemu. Wcale nie musi tego robić, ponieważ jest ona tutaj rusztowaniem, zestawem punktów orientujących nas w czasie i w dziejowych konfliktach. W centrum znajdują się małe i duże sprawy jego bohaterów, ich losy. [...] Jestem pod wrażeniem roboty rekonstrukcyjnej. Świat odmalowany przez Kobierskiego jest wiarygodny, postaci pełnokrwiste, a sytuacje przejmujące - zupełnie tak, jakby pisarz był ich świadkiem. Znać tęgiego realistę. Ale właściwie po co wsiadamy do tego wehikułu czasu? Żeby się przekonać, że uniwersalna kondycja człowiecza została wyczerpująco zapisana w Księdze Rodzaju i że niepotrzebnie trudzą się ci, którzy chcieliby zagadki losu zgłębić na własną rękę? ${ }^{4}$

Trudno nie zgodzić się z wnikliwym krytykiem - i jednocześnie trudno $\mathrm{z}$ nim, $\mathrm{w}$ innym aspekcie, nie polemizować. Jeśli bowiem skupić się na warstwie zdarzeń świata przedstawionego, Ziemię Nod należałoby rzeczywiście uznać za wyjątkowo szeroki przegląd: postaw, charakterów, wydarzeń, które wyznaczają jednostkowe losy i zbiorowe dzieje Polski pierwszej połowy XX wieku. W doświadczeniu licznej grupy bohaterów powieści, na tle których wyróżnia się - w obrębie losu żydowskiego - postać Jeszui, a wśród Polaków - rodzina Borowiczów, Kobierski pomieścił najważniejsze dylematy, wybory i tragedie znaczące dla całego pokolenia, całej formacji kulturowej. Jeszua jest świadkiem rozterek Żydów polskich w II Rzeczpospolitej (i w niewielkiej mierze je podziela, bo sam dokonał już wyboru): pomiędzy chasy-

\footnotetext{
zamiast szukania pełni, niejednokrotnie groźnej, zawsze zróżnicowanej, namawia do rekonstruowania historii przytulnej. W najczęstszych wersjach narracje wspomnieniowe nie chcą nic wiedzieć o rzeczywistych konfliktach ani o rozmaitych - w tym również potocznych - wcieleniach wartości. Zamiast tego rytualizują kontakt z przeszłością". (P. Czapliński, Wstęp, w: tenże, Wzniosłe tęsknoty. Nostalgie w prozie lat dziewięćdziesiątych, Kraków 2001, s. 5-6).

4 D. Nowacki, Ziemia Nod, „Gazeta Wyborcza” z 16.11.2010. Podobne wątpliwości i oceny zapisał Nowacki w recenzji powieści Harar: „O sile i wartości tej powieści nie decyduje [...] fabuła (nad wyraz wątła) czy zawartość problemowa utworu (zgrana do bólu), lecz piękny, nienaganny styl, a nade wszystko tyleż zachwycający, co przygnębiający nastrój zręcznie wyczarowany przez śląskiego autora. [...] Kicz emocjonalny? Bynajmniej. Kawał ładnej, stylowej, językowo dopracowanej w każdym calu prozy". Zob. tenże, Harar, "Gazeta Wyborcza" z 11.07.2005.
} 
dyzmem a asymilacją, tradycyjną religijnością a modernizacyjnym i obrazoburczym zapałem Bundu. Doświadcza upodlenia getta, tułaczki, obozu koncentracyjnego, wreszcie powraca, ciężko chory, do rodzinnego Tarnowa - by odnaleźć go nie swoim, by w końcu zgodzić się, bez przekonania, nie na aliję, nie na upragniony „powrót do ojczyzny ojców”, a na wymuszony okolicznościami wyjazd do Izraela, w obawie przed samotnością. Kobierski nie czyni zeń ikony żydowskiego losu, żydowskim losem była Zagłada. Jeszua należy do tych nielicznych, którzy przeżyli - i już nie stąpają po swojej ziemi, już nie mogą odnaleźć się w przestrzeni Tarnowa, jak zresztą w żadnej innej. Nawet obserwując powolne powojenne budzenie się do życia zniszczonego miasta, Jeszua przeżywa głębokie rozdarcie, bo z jednej strony, widząc krzątaninę, myśli: „któż w takiej sytuacji śmiał wątpić w egzystencję?”, ale z drugiej pyta dramatycznie:

Co to było za życie? Półżycie? Ćwierćżycie? Jednak stopniowanie realności. Jednak. Ile w kim zostało, ile zostało zabite, co przetrwało; czy to, co zostało, to rzetelne istnienie, czy daje szansę oddychania, co z nim można jeszcze zrobić, czy można je sprzedać, kupić lepsze? ${ }^{5}$

Jest osamotniony, nieszczęśliwy, nie potrafi zaakceptować swojego losu, nawet samego faktu, że przetrwał - cudem? Przypadkiem? Nic nie potrafi z tym zrobić, nie umie budować swojej przyszłości, może jedynie biernie trwać. Warto przypomnieć słowa Prima Leviego, który pisał o kondycji ocalonych z Holocaustu:

to nie my, którzy przeżyliśmy, jesteśmy prawdziwymi świadkami. [...] My, którzy przeżyliśmy, stanowimy odbiegającą od normy mniejszość, a nie tylko nieliczną garstkę ocalałych: jesteśmy tymi, którzy przez sprzeniewierzenie się swoim zasadom albo dzięki zaradności bądź szczęśliwemu trafowi nie znaleźli się na samym dnie. Kto zszedł na dno, kto nie uniknął wzroku Meduzy, ten nie powrócił, by dać świadectwo, albo powrócił niemy ${ }^{6}$.

Świat przedstawiony powieści Kobierskiego mieści w sobie, poprzez los wielu bohaterów, zwłaszcza zaś Jeszui i rodziny Borowiczów (której członkowie doświadczają syberyjskiej zsyłki, Katynia, pracy przymusowej w Niemczech, okupacyjnych łapanek i mordów, wreszcie - politycznej niepewności czasu powojennego), niemal pełną sumę wszelkich możliwych postaw i doświadczeń. Jest w Ziemi Nod również tragedia Cyganów, jest szmalcownictwo

${ }^{5}$ R. Kobierski, Ziemia Nod, s. 539. Wszystkie cytaty pochodzące z tego wydania oznaczam skrótem ZN, po którym podaję numer strony.

6 P. Levi, Pogrążeni i ocaleni, przeł. S. Kasprzysiak, Kraków 2007, s. 100, za: D. Szczukowski, Tadeusz Różewicz wobec niewyrażalnego, Kraków 2008, s. 133. 
i bezinteresowna pomoc Żydom, jest bezwzględne, sadystyczne okrucieństwo hitlerowców - i Niemcy-ofiary wojny, są różne postawy ludności pochodzenia austriackiego i niemieckiego - od przyjęcia volkslisty po deklarację polskości ze wszystkimi tego konsekwencjami, są gwałty i grabieże dokonywane przez żołnierzy Armii Czerwonej, jest akcja „Wisła”, terror UB, prześladowanie partyzantów Armii Krajowej, pogrom kielecki - i mozolna próba odbudowywania codziennego życia po wojnie. Można zatem zgodzić się z przywołanym wcześniej sądem Nowackiego, że „historia jest tu przepisana niemal słowo w słowo". Czyni to z Ziemi Nod powieść (tylko pozornie) artystycznie anachroniczną - bo tak usilnie, tak staromodnie dążącą ku "pełni” przedstawienia, a pisaną przecież $\mathrm{w}$ czasach utraty wiary w możliwość wyrażenia owej „pełni”. Tak ów rys „anachroniczności” ujmuje Joanna Wajs:

Narracja Ziemi Nod Radosława Kobierskiego wydaje się [...] być stworzona za pomocą przyrządu optycznego należącego do innej epoki. Wyraża bowiem swoją strukturą upartą i bardzo niemodną dziś wiarę w Całość. Struktura ta podporządkowana została zasadom wielkiego realizmu, pozwala na epicki rozmach [...]. Z początku te wszystkie elementy mogą wprawić $\mathrm{w}$ zakłopotanie, każą pytać, czy pisarz współczesny posiada jeszcze środki (i zaufanie czytelnika empirycznego) konieczne do wzniesienia konstrukcji o takim zasięgu i rozmachu. Łatwo w to wątpić, choćby dlatego, że znamy już klasyczny literacki motyw tworzenia mapy w skali 1:17.

Nic w powieści nie jest zasłonięte, wszystko zostało opisane, nawet najokrutniejsze zbrodnie. Na zimno. Czy zaproponowana przez Kobierskiego konwencja to rzeczywiście zabieg anachroniczny? Przeciwnie: pisarz celowo sięga - świadomy niemożności artystycznej reprezentacji Zagłady (a może szerzej, ogólniej: tragicznego wojennego losu), niemożności znalezienia artystycznego języka - po beznamiętną drastyczność i dosłowność, dające efekt katalogowania makabrycznych zbrodni.

Kluczem do zrozumienia zamysłu autorskiego wydaje się zatem nie tyle sam historyczny weryzm, wielość pozaliteracko poświadczonych zdarzeń, co sposób ich uobecnienia $\mathrm{w}$ fikcjonalnym świecie powieści. Pozorne wrażenie „pełni” historycznego fresku, powierzchowne zaledwie wrażenie spójnej opowieści - osiągnął Kobierski środkami jak najbardziej współczesnymi, ponowoczesnymi, właśnie w przekonaniu o niemożności zbudowania wielkiej narracji. Posługuje się zatem epizodem, obrazkiem, wielością i drobiazgowością opisów, sporządza swoiste inwentarze miejsc, przedmiotów i wyglądów

\footnotetext{
7 J. Wajs, Mapa (końca) świata. O „Ziemi Nod" Radostawa Kobierskiego, http://cwiszn.pl/files/ files/wajs_114.pdf [dostęp 12.05.2012].
} 
- pozostających $\mathrm{w}$ rozsypce, $\mathrm{w}$ jakimś fabularnym nieuzgodnieniu, $\mathrm{w}$ jakiejś wzajemnej nieprzystawalności ${ }^{8}$. W odległy sposób wiąże to powieść Kobierskiego z Pasażami Waltera Benjamina - swoistą kolekcją fragmentów, zapisków, komentarzy, cytatów, obrazów 9 .

Kobierski pokazuje $\mathrm{w}$ gruncie rzeczy zaledwie złudzenie, że coś naprawdę da się o ludzkim losie, o doświadczeniu Zagłady, doświadczeniu śmierci pewnego świata powiedzieć. Nie można tego wypowiedzieć, można tylko opowiadać, ale mozaika nie ułoży się w całość. Pozorną całością - i tak utraconą bezpowrotnie wraz z wojną - było też życie społeczności Tarnowa w dwudziestoleciu. Jego zrekonstruowaniu posłużyła ogromna praca dokumentacyjna wykonana przez autora - poznawanie historycznych źródeł ${ }^{10}$, a ponad wszystko: topografii miasta i geografii jego okolic, oraz rozmowy z mieszkańcami Tarnowa ${ }^{11}$.

Ziemia Nod (ziemia błądzenia, zważywszy na znaczenie hebrajskiego czasownika nod) pojawia się w Księdze Rodzaju jako miejsce, do którego udał się Kain po zabiciu swojego brata. Tam, po narodzinach syna, Henocha, wzniósł miasto, które nazwał jego imieniem ${ }^{12}$. To pierwsze miasto wymienione $\mathrm{w}$ Biblii, nieopisane, nieskonkretyzowane co do położenia czy wyglądu, można byłoby zatem potraktować jako prawzór miasta - domeny błądzących. Miasta, o którym nic nie wiemy ponad to, że jest siedzibą zagubionych, a raczej może - samym stanem zagubienia. Stąd blisko już ku alegoryzującemu, uniwersalizującemu ujęciu miasta jako metafory (kultury, prawideł życia społecznego etc.). Jednak Kobierski podąża inną drogą niż

8 Dlatego nie można zgodzić się w pełni z uwagami Agnieszki Nęckiej, tak komentującej konstrukcję powieści: „To, co stanowi wielką zaletę Ziemi Nod - jej niebywały rozmach epicki - jest również jej największą wadą. Momentami trudno nadążyć za zmieniającymi się niczym w kalejdoskopie scenami i wątkami. Wydaje się, że autor mimo wszystko zbytnio zawierzył opowieści recyklingowej” (A. Nęcka, Błądzić jest rzecza ludzka, „Nowe Książki” 2011, nr 1, s. 49).

9 Miasto jest dla Benjamina „"pretekstem mnemotechnicznym» do snucia opowieści”. M. Nieszczerzewska, Narracje miejskiej wyobraźni, Poznań 2009, s. 67.

10 Kobierski wspomina choćby o tarnowskim tramwaju, kursującym w latach 1911-1942, o przedwojennych wyścigach samochodowych ulicami miasta, organizowanych przez księcia R. Sanguszkę. Także przywołane w powieści drugoplanowe czy epizodyczne postaci pozostają w zgodzie z zapiskami historycznymi (m.in. Adam Marszałkowicz, przedwojenny komisarz rządowy; Mieczysław Brodziński, ostatni przedwojenny prezydent miasta; biskup Lisowski; komunista, I sekretarz Komitetu Powiatowego PPR Stanisław Anioł; urodzony w Tarnowie Józef Cyrankiewicz; Norbert Lippoczy, właściciel składu win i społecznik; Kazimiera Kaliszewska, śpiewaczka jazzowa).

11 Rozmowy te dotyczyły także doświadczeń wojennych. O ile postać Jeszui jest fikcyjna, to na losy rodziny Borowiczów złożyły się opowieści prawdziwych osób, nagrane przez Kobierskiego (zaświadczył to autor w prywatnej rozmowie).

12 Księga Rodzaju 4, 16-17. 
ta dominująca $\mathrm{w}$ dziełach literackiego modernizmu ${ }^{13}$. Pisarz akcentuje konkretny, przestrzenny, geograficzno-topograficzny aspekt świata powieściowego. (Re)konstruuje siatkę ulic przedwojennego Tarnowa w zgodzie z historycznymi planami ${ }^{14}$. Niezmiernie ważne i konsekwentne w kreowaniu zdarzeń i bohaterów jest właśnie ich umiejscowienie - $\mathrm{w}$ realnej przestrzeni Tarnowa czy otaczających go miejscowości. Poniższe fragmenty świetnie ilustrują technikę pisarską Kobierskiego:

Staw między budynkami kolejowymi a korytem Wątoku też wystąpił z brzegów i podtopił domy na Grunwaldzkiej. Minęli baraki na Strusinie. Za kępą młodych brzózek wyłoniła się wyboista droga wiodąca w kierunku Góry Świętego Marcina, Josek jednak ściągnął lejce i wóz wjechał w Zamkową, w szpaler pochyłych wierzb, migoczących srebrnymi liśćmi. Anna spojrzała w stronę cmentarza, ale jej wzrok przyciągnęła złota kopuła Synagogi Nowej. Nigdy jej nie widziała z bliska. Nawet w święto Jom Kippur chodziła do bożnicy na placu Rybnym. A przecież było tak niedaleko. Wystarczyło przejść Wałową i na placu Dożywocie skręcić w lewo [ZN, s. 74].

Pogasły wszystkie światła na Lwowskiej, Nowej, Folwarcznej, Dębowej, Olejarskiej, w domach przy placu Rybnym, Dożywociu, Burku i Targowicy. Zamilkły podwórka, sienie czynszowych kamienic i gwarne dotąd sutereny. Miasto wypełniły zapachy gotowanych ryb, czosnku, fasoli i kasz, siekanych wątróbek, kugli ziemniaczanych i czerwonego barszczu. Świat na powrót, na jeden dzień, stawał się jednością [ZN, s. 219].

To precyzyjne malowanie mapy przypomina prozę wielkiego patrona Ziemi Nod Brunona Schulza ${ }^{15}$ (po części też Zmierzchy $i$ poranki Piotra

13 O kreacjach miasta nierzeczywistego, pozbawionego nazwy i realiów geograficznych, regionalnych czy narodowych, jako uniwersalnej alegorii nowoczesności w literackim modernizmie pisze: E. Rybicka, Geopoetyka (o mieście, przestrzeni i miejscu we współczesnych teoriach i praktykach kulturowych), w: Kulturowa teoria literatury. Główne pojęcia i problemy, red. M.P. Markowski, R. Nycz, Kraków 2012, s. 481.

14 O terenie tarnowskiego getta, na wschód i południe od Rynku, zob.: www.sztetl.org.pl/ $\mathrm{pl} /$ article/tarnow/13,miejsca-martyrologii/1177,getto-w-tarnowie/ [dostęp 12.05.2012].

15 Por. także barwne, bogate w szczegóły, poetyckie opisy Tarnowa w Ziemi Nod (np. na s. 62: „Pod sklepami strychów wisiały szare kule niczym lampiony, w których dawno wygasło światło, i stamtąd każdego dnia wyruszały na krótki bój armie rozjuszonych robotnic, obsiadały baldachimy barszczu i dzięgielu, rozety nagietków, dywany rozchodnika i macierzanki. Nad dzikim ogrodem unosiły się nieskończone, nudne prymy, krótkie sekundy dźwięku owadzich skrzydeł i wprawiały w ruch także powietrze, które leniwie i rozkosznie falowało"; na s. 109: „Jesienią Tarnów ogarniała senność. Niczym motyl, który dni barwnych wzlotów ma już za sobą, zapadał w długi letarg, z którego wybudzić mógł się tylko w sytuacji bez precedensu, albowiem $\mathrm{z}$ roku na rok uodparniał się na poprzednie przebudzenia i trzeba było nie lada wysiłków, by przypomniał sobie o własnej pozycji, zapomniał o roli prowincjonalnej mieściny, do jakiej sprowadzała go bliskość innego, niegdyś stołecznego miasta"). 
Szewca ${ }^{16}$, kontemplacyjną opowieść o przedwojennym żydowskim Zamościu), spełnia jednak inne funkcje, choć punkt wyjścia jest podobny. Jak trafnie opisał ów punkt Jerzy Jarzębski:

Pierwszym ośrodkiem, wokół którego układają się Schulzowskie obrazy, będzie - mimo wszelkich możliwych zastrzeżeń - rzeczywistość fizyczna, społecznie sprawdzalna. [...] Wszystkie, fantasmagoryczne nawet, obrazy domu, ogrodu, miasta, najbliższej okolicy kryją więc w sobie jakąśs stałą, namacalne, niezmienne jądro ${ }^{17}$.

Schulz zdaje się pisać w przekonaniu o możności odnalezienia - poprzez dokonanie drobiazgowego studium konkretnego miejsca, nawet w całej jego zmienności i w istocie niepochwytności, poprzez wyrysowanie planu - głębokiego, ukrytego tam sensu świata ${ }^{18}$. Krzysztof Stala w szkicu Architektura Schulzowskiej wyobraźni zauważył, że:

Nawet niezbyt uważna lektura wyławia w prozie Schulza natarczywą powtarzalność obrazów - głębi, sedna, rdzenia, matecznika, gniazda, jądra i tkwiących $\mathrm{w}$ tych miejscach idei, istoty, esencji. Świat Schulza jest jak ogromne sito, przez którego dziury wyobraźnia przechodzi na tamtą stronę rzeczy lub w innym przekroju staje się „łuszczącą się płatek po płatku cebulą" czy teatrem, którego zasłony zapraszają do wnętrza ${ }^{19}$.

Mówiąc słowami węgierskiego modernisty, Dezsö Kosztolányiego, Schulz budował literacki świat swojego Drohobycza jakby w przekonaniu, że w przestrzeni małego miasta „życie duchowe się potęguje, nie rozszerza się, tylko pogłębia, staje się gęste, intensywne, dziwne" ${ }^{20}$. Schulzowska architektura przestrzeni służyła zatem próbie pochwycenia pełni, pod tym, co realne, poprzez realne - twórca poszukuje głębiej.

16 P. Szewc, Zmierzchy i poranki, Kraków 2000.

17 J. Jarzębski, Wstęp, w: B. Schulz, Opowiadania. Wybór esejów i listów, Wrocław 1989, s. XXXVIII.

18 Znamienne są słowa Brunona Schulza o strukturze pamięci i świata: „Nie wiem, skąd w dzieciństwie dochodzimy do pewnych obrazów o rozstrzygającym dla nas znaczeniu. Grają one rolę tych witek $w$ roztworze, dookoła których krystalizuje się dla nas sens świata". Za: I. Witz, Bruno Schulz, w: tegoż, Obszary malarskiej wyobraźni, Kraków 1967, s. 44. Cyt. za: M. Nieszczerzewska, Narracje miejskiej wyobraźni, s. 67.

19 K. Stala, Architektura Schulzowskiej wyobraźni, w: Czytanie Schulza. Materiały międzynarodowej sesji naukowej „Bruno Schulz - w stulecie urodzin i pięćdziesięciolecie śmierci. Instytut Filologii Polskiej Uniwersytetu Jagiellońskiego", Kraków, 8-10 czerwca 1992, red. J. Jarzębski, Kraków 1994, s. 193.

20 D. Kosztolányi, Önmagamrol, w: tegoż, Hátrahagyott müvei, tom III, Budapest 1941, s. 287, za: J. Reiman, "Mój ojciec wstępuje do strażaków”, czyli recepcja Schulza na Węrzech, przeł. J. Reiman, w: Czytanie Schulza, s. 179. Reiman wskazuje na pewną bliskość Schulza i Kosztolányiego. 
Inaczej u Kobierskiego - starannie literacko (re)konstruowany plan Tarnowa nie odkrywa owej Całości - bo odkryć się jej nie da, pozostanie niepochwytną tajemnicą, co najwyżej przeczuciem. Czemu zatem służy tak starannie zbudowana, $\mathrm{z}$ realnych elementów, topografia miasta czy mapa jego okolic w Ziemi Nod?

Miasto nad Białą i Dunajcem, w niezwykłej antykwarycznej precyzji opisów, jest w powieści Kobierskiego głównie bytem tekstowym. Nie chodzi pisarzowi o tradycyjnie realistyczne przedstawienie przestrzeni miejskiej ${ }^{21}$. Tarnowskie place i ulice, domy, kościoły i synagogi podporządkowane zostały kreowaniu bohaterów świata przedstawionego. Właściwie to nie oni kreują przestrzeń miasta, przeżywając ją, uczestnicząc w niej22, ale to właśnie owa przestrzeń jest narzędziem w rękach pisarza do budowania postaci. Stworzona przez Kobierskiego - (od)tworzona z realnych gazet i wspomnień - przestrzeń determinuje los bohaterów ${ }^{23}$. Dlatego właśnie tak ważne wydają się wszelkie wskazówki co do konkretnych miejsc na planie Tarnowa. Są znakami określającymi przynależność społeczną, religijną czy etniczną poszczególnych osób. Pytanie o tożsamość wiąże się tu bezpośrednio z pytaniem o to, skąd się jest i gdzie się jest ${ }^{24}$. Opowieść o mieście staje się zatem narracją o tożsamości zamieszkujących je postaci ${ }^{25}$.

21 Tarnów nie jest też samoistnym, niepowtarzalnym i niezastępowalnym bohaterem powieści Kobierskiego, jak była nim Łódź w Ziemi obiecanej Reymonta. Nie jest - mimo ujawnianych $\mathrm{w}$ wypowiedziach pozapowieściowych osobistych więzi pisarza z miastem, które pozwalałyby rozpatrywać Ziemię Nod także w kategoriach postpamięci.

${ }^{22} \mathrm{~W}$ prozie dwudziestowiecznej istotna była - posługując się terminem M. Dąbrowskiego „interioryzacja opisu”. M. Dąbrowski, Polska awangarda prozatorska, cz. 1, Warszawa 1995, za: D. Korwin-Piotrowska, Problemy poetyki opisu prozatorskiego, Kraków 2001, s. 31.

23 Kobierskiego nie interesuje zatem „oddanie stanu ducha” mieszkańców Tarnowa poprzez zindywidualizowaną, podporządkowaną emocjom kreację miejskiej przestrzeni - a był to jeden z zabiegów charakterystycznych dla powieści modernistycznych. Zob. M. Nieszczerzewska, Narracje miejskiej wyobraźni, s. 78; ponadto: M. Głowiński, Powieść młodopolska. Studium z poetyki historycznej, Wrocław 1969, s. 128; D. Korwin-Piotrowska, Problemy poetyki opisu prozatorskiego, s. 29 i n. Przeciwnie, doświadczenie pewnego precyzyjnie zarysowanego w powieści terytorium to dla wykreowanych postaci Ziemi Nod część doświadczania siebie.

${ }^{24}$ Zob.: E. Rybicka, Zwrot topograficzny $w$ badaniach literackich. Od poetyki przestrzeni do polityki miejsca, w: Kulturowa teoria literatury. Poetyki, problematyki, interpretacje, red. T. Walas, R. Nycz, Kraków 2012, s. 333.

${ }^{25}$ Literacka propozycja Kobierskiego przywołuje na myśl, w porządku pozaartystycznym, narracyjną koncepcję tożsamości Charlesa Taylora, ufundowaną na przekonaniu, że rozumienie siebie ma strukturę narracji. Jak pisze K. Rosner: „Dla Taylora narracyjna struktura rozumienia jest, jak widać, prostą konsekwencją czasowości naszego sposobu bycia”. Zob. tenże, Narracja, tożsamość i czas, Kraków 2003, s. 35. 
W toku zdarzeń powieściowych Tarnów staje się następnie figurą odrzucenia i Zagłady, figurą śmierci i cierpienia, figurą utraty. Służy temu zmiana, jakiej dokonał autor w sposobie prezentowania realiów i faktów okresu wojennego w stosunku do wcześniejszych. Okupacyjne losy bohaterów zdają się jakby w mniejszym stopniu związane z konkretnym miejscem. Rzadziej narrator przywołuje nazwy ulic, budynków, wsi, rzadziej kreuje układy przestrzenne krajobrazu. Przedwojenny Tarnów jawił się jako ostoja tradycji, stałości, przewidywalności i pewnej ciągłości losu ${ }^{26}$ - dzięki aptekarskiej wręcz niekiedy precyzji opisu ${ }^{27}$. Każda wędrówka którejkolwiek z postaci w przedwojennym Tarnowie miała swój wymiar topograficzny, była zawsze rysowaniem jakiegoś planu bądź mapy. Każda restauracja, sklep, kamienica, szkoła, kościół czy bożnica w przedwojennej części opowieści zaopatrzone są przez narratora $\mathrm{w}$ informacje o ich położeniu na planie miasta: pada nazwa ulicy czy placu, mówi się o tym, jak można tam dojść (jest to zresztą zabieg tak konsekwentny, że dla czytelnika nieznającego Tarnowa czy jego okolic wręcz niekiedy nużący). Na tym tle tym wyraźniej widać, że doświadczenie okupacyjne, zarówno codzienne, jak i to krańcowe, tragiczne - jest na poły zawieszone w jakimś "nigdzie”, jest ulokowane poza miejscem - zatem staje się jakoś niewyrażalne. Kobierski i w tych partiach powieści używa nazw miejscowych, jednak, podkreślmy jeszcze raz, zdecydowanie rzadziej, a co ważniejsze, narracja nie rekonstruuje już ich siatki, linii łączących poszczególne punkty. Jeden z bohaterów utworu, Willner, odkrywa w znalezionej walizce martwe żydowskie dziecko:

Tamtego dnia coś w nim umarło. Skapitulował. Zamknął się w swoim ciasnym mieszkaniu i nie wychodził. Żył w ciemności. Niby pogodził się ze stratą, ale tak naprawdę nigdy jej nie zaakceptował. Wojna trwała nadal, choć ucichły wystrzały, łoskoty wagonów, na rynku nie było już patok, którymi wywożono ciała zabitych, i wszędobylskiego zapachu wapna, którym posypywano ulice i place $\mathrm{w}$ mieście. Wojna przeniosła się z placów i ulic do wewnętrznych przestrzeni, do umysłu. Tam trwała nadal, odtwarzała się jak zacięta płyta dzień po dniu. Każdy szelest, skrzypnięcie desek w podłodze, kroki na schodach, krzyk dziecka w sieni, warkot silnika, pisk opon kojarzył mu się tylko z jednym [ZN, s. 472-473].

\footnotetext{
${ }^{26}$ Na podobny sposób kreowania przestrzeni miejskiej w opowiadaniach Schulza, ,gdzie nie ma miejsca na przeżywanie szoku, zmiany, na to, co zachodzi nieoczekiwanie", zwraca uwage M. Nieszczerzewska, Narracje miejskiej wyobraźni, s. 81.

27 D. Korwin-Piotrowska, pisząc o obecności autentycznej onomastyki i topografii w nouveau roman, wskazuje na bliskość zastosowanego w tej konwencji typu opisu z praktykami charakterystycznymi dla filmu. Elementy „techniki filmowej” w opisie przestrzeni odnaleźć można także w Ziemi Nod. Zob. tejże, Problemy poetyki opisu prozatorskiego, s. 37.
} 
Jak zauważa Elżbieta Rybicka, zwrot topograficzny w badaniach literackich i kulturowych, ale też na gruncie socjologii, nauk politycznych, antropologii, filozofii, historii i historii sztuki zbudowany jest wokół consensusu co do statusu przestrzeni jako tekstu, jako „społecznego konstruktu istotnego do rozumienia zróżnicowanych historii ludzkich podmiotów i do wytwarzania zjawisk kulturowych" ${ }^{28}$. Wychodząc z tych przesłanek, można uznać taką swoiście nieprzestrzenną kreację Kobierskiego wojennych losów bohaterów powieściowych (bohaterów budowanych przecież na kształt postaci realnych, z antykwaryczną dbałością o życiowe prawdopodobieństwo) za znak utraty przez nich tożsamości, za wejście w domenę pustki, domenę Zagłady. Ale, co chyba jeszcze istotniejsze, wręcz kluczowe dla sensu powieści Kobierskiego - ta „utrata miejsca” jest znakiem niemożności wyrażenia doświadczenia Zagłady w społecznym, konwencjonalnym kodzie języka i kultury. Jedyne, co możliwe, gdy mowa o niepochwytnym ludzkim losie, to (re)konstruowanie pojedynczych anegdot, obyczajowych obrazków - i rysowanie ludzkich śladów wędrówki w przestrzeni. Ale te ślady się nie sumują, nie tworzą spójnej panoramy, nie mogą być $w$ istocie - przy głębszym (może wrażliwszym?) oglądzie - rozpatrywane $\mathrm{w}$ kategoriach typowości, w porządku ponadjednostkowym, bo byłoby to zbagatelizowaniem, strywializowaniem wyjątkowości i pojedynczości ludzkiego losu i cierpienia. Są niepowtarzalne. Miejsce bezpośrednio wiąże się w powieści z konkretnym ludzkim doświadczeniem. Tarnów zatem to mało czytelny plan ogromnie wielu ścieżek/losów jego polskich, żydowskich, cygańskich, węgierskich, ukraińskich, niemieckich mieszkańców - i jednocześnie, paradoksalnie, miejsce nigdy przez nich niezdobyte, niepodporządkowane, obce i zimne. Wraz z ich śmiercią, wobec tego, co się zdarzyło, powinien przecież zniknąć - konstatuje Jeszua, wracając doń z wojennej tułaczki:

kiedy [...] mijał wylot ulicy Bandrowskiego i wchodził na Krakowską, pomyślał, że wojna powinna była zniszczyć wszystko. To nieludzkie, pomyślał również, że dla jakichś niezrozumiałych kaprysów wojna pewne obszary pozostawia nietknięte. Ile by dał, żeby to miasto leżało teraz w gruzach! Żeby zamiast zapachu liści i kwiatów, rosołu i lizolu czuć swąd pogorzelisk, gryzący dym! By wszędzie zalegała cisza miejsca wykreślonego z map realności! [ZN, s. 500]

Powinny zniknąć - w optyce ocalonego z Zagłady - przestrzenie miasta, bo były tak bardzo związane, wręcz tożsame z losem zabitych i wypędzonych

28 Por.: E. Rybicka, Zwrot topograficzny w badaniach literackich, s. 315. Fragment w cudzysłowie: B. Warf, S. Arias, Introduction: The Reinsertion of Space into the Social Sciences and Humanities, w: The Spatial Turn. Interdisciplinary Perspectives, ed. B. Warf, S. Arias, London, New York 2009, s. 1, za: E. Rybicka, Zwrot topograficzny w badaniach literackich, s. 315. 
mieszkańców ${ }^{29}$. Po zakończeniu koszmaru wracają jednak ludzie i codzienne banalne zdarzenia. Wracają też $\mathrm{w}$ narracji (choć nie $\mathrm{z}$ taką samą intensywnością jak uprzednio) nazwy, wraca siatka ich połączeń: (re)kreacji podlega topografia miasta. Jeszua, ocaleniec z Zagłady, zauważa w finale powieści, w obliczu krańcowego zagubienia, w poczuciu swojego nie-miejsca:

Nie ma pustych miejsc [...]. Życie popychane jakąś niewyobrażalną siłą, pod ogromnym ciśnieniem, wypełnia wszystko, każdą sferę przestrzeni. Wydaje się nam, że panujemy nad tym procesem i możemy nim kierować, ale to jest złudzenie, jeszcze jedna żałosna i fałszywa namiastka. Człowiek zawsze błądzi na ziemi wygnania [ZN, s. 603].

To nie jest hymn ku czci siły życia! Tarnów zginął bezpowrotnie. Tamten Tarnów. Jednocześnie trwa, zupełnie inny: dla tych, którzy będą w nim na nowo wytyczać swoje ścieżki.

W Ziemi Nod Radosław Kobierski kreuje (nieco po Schulzowsku) Tarnów, miasto i jego najbliższą okolicę. Stanowi ono sferę codziennego, konsekwentnie jednostkowego działania, przestrzeń przeżyć, a nie architektoniczno-urbanistyczny koncept. Jest też tekstowym znakiem określającym przynależność społeczną, religijną czy etniczną poszczególnych osób oraz ich tożsamość. Bliskie to ponowoczesnej refleksji nad miastem Michela de Certeau, dla którego praktyka codziennego doświadczenia miasta jest niczym indywidualny akt mowy ${ }^{30}$, pojedynczy głos.

\section{Geography and Topography of Ziemia Nod by Radosław Kobierski}

\section{Summary}

The article constitutes an attempt at analysing the function of creation of space in Radosław Kobierski's (b. 1971) postmodern novel Ziemia Nod (Warszawa 2010). The novel recounts the fates of several dozen characters, Poles and Jews, between the interwar period and the first few years of the Polish People's Republic, who all inhabit the topography of Tarnów as reconstructed by Kobierski in literature with an antiquarian exactness, care, and precision. The pre-war space of the city is a textual sign defining social,

\footnotetext{
29 Jeden z bohaterów, Józio, wyobraża sobie dalsze trwanie miasta wojennej pożogi i śmierci w zaświatach [ZN, s. 476-477].

30 Zob.: M. de Certeau, Marches dans la ville, w: tenże, L'invention du quotidien, t. 1, Paris 1990, za: E. Rybicka, Geopoetyka (o mieście, przestrzeni i miejscu we wspótczesnych teoriach i praktykach kulturowych), s. 474 .
} 
religious and/or ethnic belonging of individual characters as well as their identity. During the war and after its conclusion the abovementioned space undergoes disintegration, and Tarnów becomes a figure of the Holocaust, death and irreparable loss. 